\title{
HEBEL E KAFKA
}

ELIAS CANETTI

Tradução do Alemão de Samuel Titan JR.

[*] Conferência proferida por ocasião da outorga do Prêmio Johann Peter Hebel, a 10 de maio de 1980 , em Hausen im Wiesenthal e recolhida no volume Über die Dichter (Munique: Hanser, 2004), a ser lançado no Brasil pela editora José Olympio (Rio de Janeiro). (C) 1980 Carl Hanser Verlag (Munique/Viena) e (C) 2003 Herdeiros de Elias Canetti.
Senhoras e senhores!

Conheci a Caixinha de tesouros aos treze anos, quando freqüentava a escola cantonal de Zurique. Naquela escola eu aprendi o que significam os bons professores. Mas o melhor professor que tive então foi Johann Peter Hebel. Ele veio ao mundo nesta mesma data, há duzentos e vinte anos. Não são muitos os que seguem ensinando tanto tempo depois da morte.

Ele possui aquele dom que esperamos ver num professor: fala claramente e fala para todos. Tem sede de saber e aprendeu muita coisa, mas isso só se nota quando ele transmite um quinhão de conhecimento: explica de tal modo que ninguém esquece mais. Leva todos a sério e sabe ouvir antes de responder, não para um fim estreito, mas porque participa do impulso alheio. Quem lê a Caixinha de tesouros não tem jamais a sensação de que ali haja coisa de somenos: ele sabe relatar alguma coisa de notável sobre o que quer que seja, tudo importa, porque tudo tem vida própria, não apenas a espécie humana, mas também a toupeira, a aranha, o lagarto e até os planetas e cometas, como se também estes fossem vivos.

Sua linguagem parece ter surgido expressamente para ele. Seu frescor está por encontrar igual na literatura. Não há palavras gastas, elas não se afrouxam nem rebentam de soberba, e a noção que fazemos da linguagem em geral torna-se verdade nele: cada uma das histórias que lemos nos toma e nos abandona com expectativa.

Muitos já observaram que as histórias de almanaque de Hebel exerceram influência sobre Franz Kafka. Em várias ocasiões formularam-se hipóteses a respeito, mas não tardou quem dissesse não haver provas. Por uma dessas surpreendentes circunstâncias da vida que parecem tiradas de uma história de almanaque, creio que posso contribuir com alguma coisa de mais confiável a respeito.

No ano de 1936, em Grinzing, um lugarejo nos vinhedos perto de Viena onde eu morava na época, recebi a visita do recitador Ludwig Hardt. Nos anos entre as duas guerras, Ludwig Hardt tinha a fama 
justificada de ser o mais importante recitador em língua alemã. Eu já o ouvira recitar várias vezes e o admirava muito, de modo que considerei sua visita uma distinção e uma honra. Era um homem baixo, elegante e extraordinariamente irrequieto, que não parava nem se sentava um instante sequer. Andando de cá para lá no cômodo em que o recebi, mantinha a mão direita afundada no bolso do casaco e brincava com o que parecia ser um livrinho. Finalmente, tirou-o para fora - era mesmo um livro-,estendeu-o para mim com um gesto solenee disse: "Quervero que possuo de mais valioso? Vem comigo para onde eu for, não o confio a ninguém. Quando vou dormir, eu o guardo embaixo do travesseiro".

Era a Caixinha de tesouros, uma edição em formato pequeno do século passado. Abri o livro e li a dedicatória:

A Ludwig Hardt, para dar uma alegria a Hebel, de Franz Kafka

Era o exemplar da Caixinha de tesouros do próprio Kafka, que também costumava carregá-lo consigo. Ao ouvir Ludwig Hardt recitar Hebel pela primeira vez, ficou tão emocionado que lhe presentou seu exemplar com aquela dedicatória. "Quer saber o que Kafka me ouviu recitar naquela vez?”, perguntou Hardt. "Sim, claro”, eu disse. Então ele recitou, de cor, como sempre - o livro estava em minha mão -, nessa seqüência: Noite insone de uma nobre senhora, as duas peças sobre Suvórov, Equívoco e, por último, Reencontro inesperado.

Quem dera que cada um dos senhores tivesse ouvido esta última história recitada por Hardt. Isso se deu doze anos depois da morte de Kafka, e as mesmas palavras que ele ouvira da mesma boca chegavam agora a meus ouvidos. Nós dois nos calamos, pois percebemos que tínhamos vivido um novo desdobramento da mesma história. Então, Hardt perguntou: "Quer saber o que Kafka me disse?". Não esperou minha resposta e continou: "Kafka disse: 'Essa é a história mais maravilhosa que há!'”. Eu pensava a mesma coisa e ainda hoje penso, mas já era suficientemente notável ouvir aquele superlativo de Kafka repetido por alguém que fora agraciado, por recitar aquela história, com o exemplar da Caixinha de tesouros do próprio escritor. Os superlativos de Kafka, como os senhores sabem, são muito contados.

Eu me perguntei se devia lhes falar hoje sobre o que Hebel significa para mim e concluí que seria mais correto, e também mais conveniente, tornar pública esta prova da mais profunda influência que Hebel exerceu sobre a literatura universal. Guardo este recado comigo há quarenta e quatro anos, como a seu tempo fizeram Ludwig Hardt e, antes dele, Franz Kafka.

Agradeço-lhes a distinção que traz o nome de Hebel e o convite a esta cerimônia. Agradeço ao professor Baumann por suas palavras, que tanto me embaraçam.

Elias CANeTti (1905-1994), escritor e ensaísta, ganhou o Prêmio Nobel de Literatura em 1981. 
EMBRANCO

247 


\section{EMBRANCO}

248 